\title{
Prevalence of environmental barriers in children and adolescents with physical disabilities: a cross-sectional study
}

\author{
Leilan Santos Soares', Élida Rayanne Viana Pinheiro Galvão', Isabelle Ribeiro Barbosa', \\ Haryelle Náryma Confessor Ferreira', Rafaela da Silva Cruz', Carla Patricia Novaes dos Santos Fechine², \\ Alinne Beserra de Lucena Marcolino ${ }^{3}$, Sheva Castro Dantas de Sousa², Egmar Longo ${ }^{1}$
}

\begin{abstract}
Introduction. Children and adolescents with physical disabilities (PD) still do not have the same opportunities as their non-disabled peers, which may be due to environmental factors and their effect on participation. Objective: The aim of this study was to evaluate the prevalence of environmental barriers in children and adolescents with PD and their associated factors in two states of Northeastern Brazil. Method. The parents or caregivers of 71 children and adolescents aged 18 years and younger with PD were interviewed, using a sociodemographic questionnaire and the Craig Hospital Inventory of Environmental Factors (CHIEF), which assesses the frequency and extent of environmental barriers. Results. The greatest environmental barriers were for Service and Assistance. In the Service and Assistance and Physical/Structural domains, the frequency of barriers was monthly, while Attitude and Support and Policies barriers were less frequent. In all the domains, the parents reported that the problems were serious. Children and adolescents with PD who walked faced barriers more frequently than those who used a wheelchair or were carried and those living in Rio Grande do Norte had more perceived barriers in the Policies domain. Conclusion. These results lead to a reflection on the role of the environment and how each state conducts national public policies aimed at children with disabilities. This can be a step towards improving the lives of children with disabilities in Northeastern Brazil, transforming environmental barriers into environmental facilitators.
\end{abstract}

Keywords: Disability; Environment; Participation; Children; Adolescents.

\section{INTRODUCTION}

Approximately $10 \%$ of the world's population presents some type of disability, representing around 650 million people $^{1}$. In Brazil, it is estimated that 645,000 children and adolescents 19 years and younger have some type of physical disability (PD), 243,000 of whom live in the northeastern region of the country ${ }^{2}$. About 64,000 and 41,000 individuals with PD live in the northeastern states of Paraíba (PB) and Rio Grande do Norte (RN), respectively. Furthermore, the human poverty index is among the highest in the country, with $57.48 \%$ in PB and $52.27 \%$ in $\mathrm{RN}$, which reinforces the belief that disability and poverty operate in a cycle, each reinforcing the other ${ }^{3,4}$.

Although children and adolescents with disabilities have the same desires, aspirations and perspectives as their peers, they are still at a social disadvantage and participate less in leisure and educational activities when compared to their peers without disabilities ${ }^{5-13}$. Several aspects can influence the participation and quality of life of children and adolescents with disabilities ${ }^{14}$, such as personal factors, motor function, and the individual's environment ${ }^{15-17}$. In recent years, special attention has been directed to environmental factors, since they are potentially modified and can positively influence participation results ${ }^{18-21}$.

Recent data indicated that all aspects of the environment identified by the International Classification of Functioning, Disability and Health (eg, physical accessibility, services and programs, attitudes) served as a barrier, as a support, or both, for participation of children and youth with various types of disabilities. The most common facilitators involved the social support of family and friends and geographic location. The most common barriers included attitudes, physical environment, transportation, policies, and lack of support from staff and service providers ${ }^{15,18,22-29}$. Often, parents feel responsible for ensuring the right to participation in leisure activities of their children and are also the ones who best identify barriers to access to these activities. Within this perspective it is relevant to identify the main barriers and facilitators of children with disabilities according parents' perspectives.

Therefore, it is necessary to use validated and reliable assessment tools capable of quantifying the magnitude of these barriers in their various aspects from the perspective

Correspondence: Graduate Program in Rehabilitation Sciences, Universidade Federal do Rio Grande do Norte - Faculdade de Ciências da Saúde do Trairi (UFRN-FACISA), Address: Avenue Rio Branco, Santa Cruz, Rio Grande do Norte, Brazil. egmarlongo@yahoo.es. Telephone: 55 (84) $3291-2411$.

Universidade Federal do Rio Grande do Norte - Faculdade de Ciências da Saúde do Trairi (UFRN-FACISA), Santa Cruz, RN, Brasil.

Full list of author information is available at the end of the article.

Financial support: This research received financial support from the Institutional Program for Scientific Initiation Scholarships (PIBIC) (PVL12467-2015).

Submission date 05 February 2020; Acceptance 15 March 2020 Publication date 24 March 2020 
of parents of children with PD, in order to understand the individual beyond physical disability, inserted in a biopsychosocial context $\mathrm{t}^{30-33}$. This research used the Craig Hospital Environmental Factors Inventory (CHIEF) ${ }^{33,34,35}$. Its Brazilian version was validated by Furtado et al.in 2014 and has shown adequate psychometric properties and has been widely applied to samples of children, adolescents and adults with disabilities, from the perspective of parents or caregivers, or even individuals themselves ${ }^{36-42}$. Considering the lack of research on the environmental barriers of children with PD in Northeast Brazil, this study aimed to evaluate the prevalence of environmental barriers in children and adolescents with PD and their associated factors in the States of Rio Grande do Norte (RN) and Paraíba (PB).

\section{METHODS}

This is a cross-sectional study, using a convenience sample of children and adolescents with PD, aged 18 years and younger, from the states of Rio Grande do Norte and Paraíba, Brazil. Ethical approval for the study was obtained from the Bioethical Committee of the Federal University of Rio Grande do Norte (protocol no. 1.707.635). All guardians signed of the informed consent form and all children gave informed assent.

The data were collected between 2016 and 2017 at rehabilitation centers in two Brazilian states. In Rio Grande do Norte, subjects were recruited at the Specialized Rehabilitation Centers (CER). In Paraíba participants were children and adolescents followed at the Paraiba Association of Equine Therapy (ASPEQ), School Clinic of the Medical Sciences Faculty of Paraíba, Support Foundation for Disability (FUNAD) and School Clinic of the University Center of João Pessoa (UNIPÊ).

Inclusion criteria for the study were: children and adolescents with a diagnosis of physical disability, aged between 0 and 18 years. The exclusion criteria established were: children and adolescents with clinical instability who presented other types of disability than physical or those whose guardians did not sign the informed consent form.

A sociodemographic questionnaire was used to obtain information on the children and adolescents, such as gender, age, city of residence, family income, clinical diagnosis, degree of mobility, type of physiotherapy treatment, and presence of associated comorbidities and pain, in addition to the gender of the caregiver. To assess environmental barriers or facilitators, we used the Brazilian version of the CHIEF, which was validated in $2014^{37}$, exhibiting adequate psychometric properties.

The CHIEF is composed of 25 questions subdivided into 5 domains: Services and Assistance (SA): questions 1, 7, 8, 9, 10, 12 and 14, Physical/Structural (PS): questions 2 3, 4, 5, 6 and 11, Work and School (WS): questions 13, 16 and 19, Attitude and Support (AS): questions 15, 17, 18, 20, 21 and Policies (P): questions 22, 23, 24 and 25. All the questions are scored according to the frequency of barriers (1- less than monthly, 2- monthly, 3- weekly, 4- daily) and their magnitude (1- a little problem, 2- a big problem). The CHIEF has three types of scores: frequency, magnitude and frequency-magnitude (frequency $x$ magnitude), which are directly proportional to environmental barriers ${ }^{34,35}$. In the present study, barrier frequency and magnitude scores were considered.

All the data were collected by face-to-face interview with the parents or caregivers of children and adolescents with PD. Data collection was carried out in 2 stages: 1) training researchers on the instruments used at each collection site; 2) an active search at participating institutions and application of questionnaires to the parents or caregivers of children and adolescents with PD who accepted to take part in the study and gave their informed consent.

Descriptive analysis of the categorical variables was performed using absolute and relative frequencies; the quantitative variable was expressed as the mean, median and standard deviation. The chi-squared test was applied to determine the association between type of locomotion and the contextual variables. The Student's t-test, analysis of variance (ANOVA) and the Bonferroni post-hoc test were used to analyze the CHIEF domains, from the standpoint of magnitude and frequency. A 5\% significance level was considered for all the analyses and the IBM SPSS Statistics program, version 23.0 was used for processing and statistical analysis.

\section{RESULTS}

The sample included 71 children and adolescents, of both genders, whose most frequent diagnosis was cerebral palsy (table 1).

CHIEF data are illustrated in the Figure 1 and 2 (Additional file), where the greatest perceived environmental barriers by parents, in both frequency and magnitude, were related to the Service and Assistance domain, while those least reported were Work and School.

According to the parents, barriers in the Physical/Structure and Service and Assistance domains occurred monthly (SA: 42.3\%, EF: 36.6\%). In the Attitude and Support and Policies domains, less than once a month (AS: $43.7 \%, \mathrm{P}: 36.6 \%$ ). Regarding the magnitude of these barriers, most parents reported serious problems in all domains (SA: $84.5 \%$, PS: $69 \%$, WS: $19.7 \%$, AS: $40 \%$, P: $54.9 \%)$.

Table 2 shows the values of the CHIEF domains in terms of barrier frequency according to sociodemographic data. There were significant results between Service and Assistance ( $p=0.035)$ and Policies $(p=0.002)$ and type of locomotion. Children and adolescents with PD who moved by walking faced barriers more frequently than those who used a wheelchair or were carried. Children and adolescents with PD living in RN had more perceived barriers in the Policies domain $(p=0.008)$. There was significance in the relationship between the type of diagnosis and Work and School $(p=0.037)$ and Policies ( $p=0.045)$, displaying greater barrier frequency 
Table 1: Descriptive analysis of sociodemographic variables of children and adolescents and their caregivers.

\begin{tabular}{|c|c|c|c|}
\hline Variable & Category & Frequency $(\mathrm{n})$ & Percentage (\%) \\
\hline \multirow[t]{3}{*}{ Age } & $\leq 5$ years & 20 & 28.2 \\
\hline & $6-12$ years & 38 & 53.5 \\
\hline & $13-18$ years & 13 & 18.3 \\
\hline \multirow[t]{2}{*}{ Gender } & Female & 33 & 46.5 \\
\hline & Male & 37 & 52.1 \\
\hline \multirow[t]{2}{*}{ Diagnosis } & Cerebral palsy & 47 & 66.2 \\
\hline & Other diagnoses & 24 & 33.8 \\
\hline \multirow[t]{2}{*}{ Type of locomotion } & Walking & 25 & 35.2 \\
\hline & Carried/Wheelchair & 46 & 64.8 \\
\hline \multirow[t]{2}{*}{ Gender of the caregiver } & Female & 62 & 87.3 \\
\hline & Male & 09 & 12.7 \\
\hline \multirow[t]{2}{*}{ State of residence } & Paraíba & 39 & 54.9 \\
\hline & Rio Grande do Norte & 32 & 45.1 \\
\hline
\end{tabular}

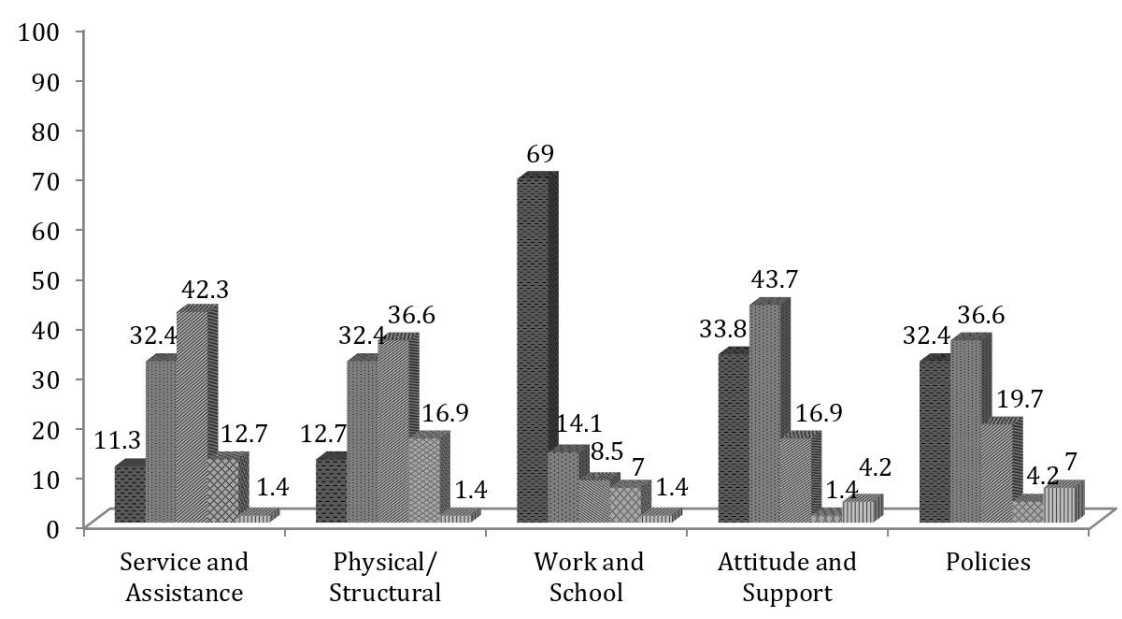

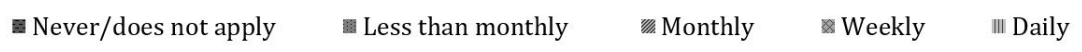

Figure 1: Barrier frequency according to the CHIEF (\%).

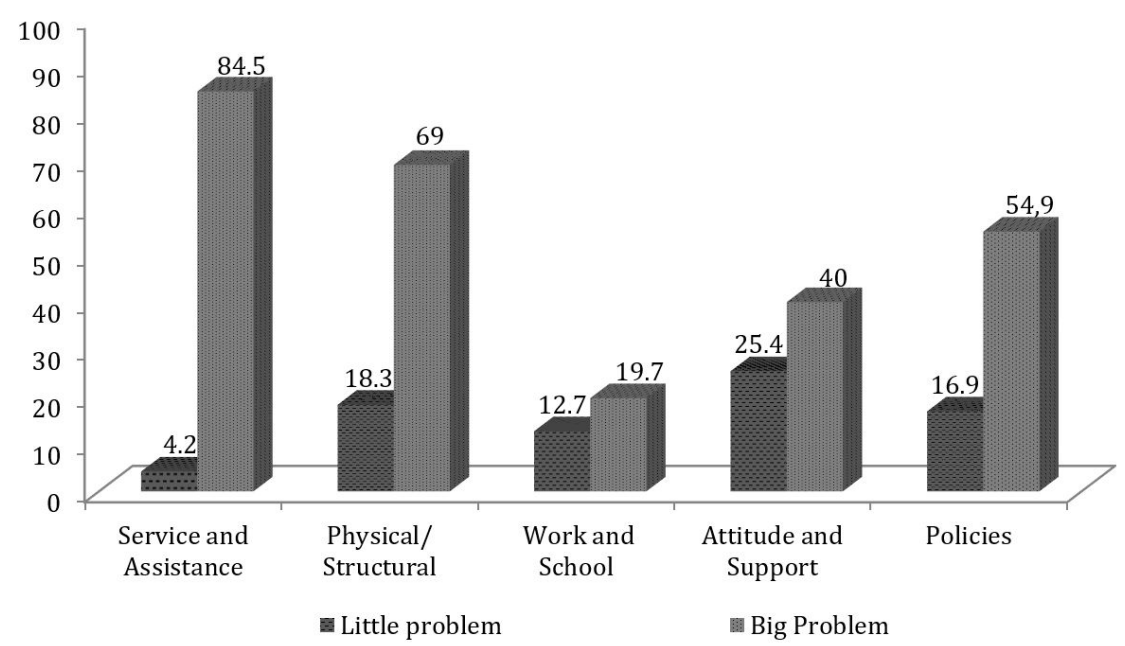

Figure 2: Barrier magnitude according to the CHIEF (\%). 
Table 2: Analysis of CHIEF domains in terms of FREQUENCY, according to the sociodemographic data of the sample. ${ }^{*} p<0.05$

\begin{tabular}{|c|c|c|c|c|c|c|c|c|c|c|}
\hline & $\begin{array}{c}\text { Service } \\
\text { and } \\
\text { Assistance }\end{array}$ & $p$-value & $\begin{array}{l}\text { Physical/ } \\
\text { Structural }\end{array}$ & $p$-value & $\begin{array}{l}\text { Work and } \\
\text { School }\end{array}$ & $p$-value & $\begin{array}{l}\text { Attitude } \\
\text { and } \\
\text { Support }\end{array}$ & p-value & Policies & p-value \\
\hline \multicolumn{11}{|l|}{ Type of locomotion } \\
\hline Walking & 1.36000 & $0.035^{*}$ & 1.17333 & 0.726 & 0.70667 & 0.067 & 0.87200 & 0.365 & 1.59000 & $0.002 *$ \\
\hline Carried/Wheelchair & 1.16460 & & 1.25000 & & 0.31159 & & 0.66522 & & 0.76087 & \\
\hline \multicolumn{11}{|l|}{$\begin{array}{l}\text { Gender of the } \\
\text { caregiver }\end{array}$} \\
\hline Female & 1.27189 & 0.297 & 1.27419 & 0.196 & 0.44624 & 0.91 & 0.75806 & 0.63 & 1.06048 & 0.878 \\
\hline Male & 0.96825 & & 0.87037 & & 0.48148 & & 0.60000 & & 1.00000 & \\
\hline \multicolumn{11}{|l|}{ State of residence } \\
\hline Paraíba & 1.31868 & 0.331 & 1.20085 & 0.815 & 0.35897 & 0.33 & 0.80000 & 0.531 & 0.74359 & $0.008^{*}$ \\
\hline $\begin{array}{l}\text { Rio Grande do } \\
\text { Norte }\end{array}$ & 1.12946 & & 1.25000 & & 0.56250 & & 0.66250 & & 1.42969 & \\
\hline \multicolumn{11}{|l|}{$\begin{array}{l}\text { Gender of the } \\
\text { child/ adolescent }\end{array}$} \\
\hline Female & 1.16450 & 0.614 & 1.22222 & 0.994 & 0.44444 & 0.989 & 0.53333 & 0.083 & 1.23485 & 0.16 \\
\hline Male & 1.26255 & & 1.22072 & & 0.44144 & & 0.91351 & & 0.86486 & \\
\hline \multicolumn{11}{|l|}{ Type of diagnosis } \\
\hline Cerebral Palsy & 1.24924 & 0.82 & 1.23050 & 0.92 & 0.29787 & $0.037 *$ & 0.70213 & 0.646 & 0.86702 & $0.045^{*}$ \\
\hline Other diagnoses & 1.20238 & & 1.20833 & & 0.75000 & & 0.80833 & & 1.41667 & \\
\hline
\end{tabular}

Table 3: Analysis of CHIEF domains in terms of MAGNITUDE, according to the sociodemographic data of the sample. ${ }^{*} p<0.05$

\begin{tabular}{|c|c|c|c|c|c|c|c|c|c|c|c|}
\hline & & $\begin{array}{c}\text { Service } \\
\text { and } \\
\text { Assistance }\end{array}$ & p-value & $\begin{array}{l}\text { Physical/ } \\
\text { Structural }\end{array}$ & p-value & $\begin{array}{c}\text { Work and } \\
\text { School }\end{array}$ & p-value & $\begin{array}{l}\text { Attitude } \\
\text { and } \\
\text { Support }\end{array}$ & p-value & Policies & p-value \\
\hline \multirow{2}{*}{$\begin{array}{l}\text { Gender of } \\
\text { the child/ } \\
\text { adolescent }\end{array}$} & Female & 1.51616 & 0.724 & 1.34899 & 0.707 & 0.48485 & 0.955 & 0.89141 & 0.224 & 1.42424 & \multirow[t]{2}{*}{$0.027^{*}$} \\
\hline & Male & 1.56956 & & 1.40721 & & 0.49550 & & 1.13468 & & 0.98423 & \\
\hline \multirow{2}{*}{$\begin{array}{l}\text { Type of } \\
\text { diagnosis }\end{array}$} & $\begin{array}{l}\text { Cerebral } \\
\text { Palsy }\end{array}$ & 1.51560 & 0.596 & 1.42872 & 0.319 & 0.34752 & $0.021 *$ & 1.02589 & 0.931 & 1.01064 & \multirow[t]{2}{*}{$0.01^{*}$} \\
\hline & $\begin{array}{l}\text { Other } \\
\text { diagnoses }\end{array}$ & 1.59891 & & 1.26806 & & 0.79167 & & 1.00764 & & 1.53819 & \\
\hline \multirow{2}{*}{$\begin{array}{l}\text { Type of } \\
\text { locomotion }\end{array}$} & Walking & 1.54095 & 0.978 & 1.28400 & 0.383 & 0.68000 & 0.143 & 1.02400 & 0.975 & 1.47667 & \multirow[t]{2}{*}{$0.03^{*}$} \\
\hline & $\begin{array}{l}\text { Carried/ } \\
\text { Wheelchair }\end{array}$ & 1.54529 & & 1.42355 & & 0.39855 & & 1.01739 & & 1.03261 & \\
\hline \multirow{2}{*}{$\begin{array}{l}\text { Gender } \\
\text { of the } \\
\text { caregiver }\end{array}$} & Female & 1.55549 & 0.679 & 1.38441 & 0.732 & 0.47312 & 0.486 & 1.03333 & 0.718 & 1.19892 & \multirow[t]{2}{*}{0.793} \\
\hline & Male & 1.46296 & & 1.30556 & & 0.66667 & & 0.92593 & & 1.12037 & \\
\hline \multirow{2}{*}{$\begin{array}{l}\text { State of } \\
\text { residence }\end{array}$} & Paraíba & 1.59890 & 0.412 & 1.37137 & 0.965 & 0.44444 & 0.525 & 1.10385 & 0.347 & 0.89316 & \multirow[t]{2}{*}{$0.001^{*}$} \\
\hline & $\begin{array}{l}\text { Rio Grande } \\
\text { do Norte }\end{array}$ & 1.47656 & & 1.37813 & & 0.56250 & & 0.91719 & & 1.54948 & \\
\hline
\end{tabular}

for participants with other diagnoses compared to those diagnosed with cerebral palsy (CP).

There was a significant association between barrier magnitude in the Policies domain and nearly all the variables analyzed, except for caregiver gender, showing that groups of female children and adolescents with other diagnoses who were able to walk and lived in RN faced barriers of greater magnitude than groups of male children and adolescents
( $p=0.027)$ diagnosed with CP $(p=0.01)$ who used a wheelchair or were carried $(p=0.03)$ and lived in PB $(p=0.001)$. There was also meaningfulness between type of diagnosis and Work and School $(p=0.021)$, where parents or caregivers of children with other diagnoses perceived greater barrier magnitude (Table 3).

According to analysis of variance of the CHIEF domains in terms of magnitude and frequency, considering the age of the children and adolescents, there was significance only 
Table 4: Analysis of variance of the CHIEF domains in terms of magnitude and frequency, considering the child's age. ${ }^{*} p<0.05$

\begin{tabular}{|c|c|c|c|c|}
\hline Frequency & Age & Variance & $\mathbf{F}$ & $p$-value \\
\hline \multirow{3}{*}{$\begin{array}{l}\text { Service and Assistance } \\
6-12 \text { years } \\
13-18 \text { years }\end{array}$} & $\leq 5$ years & .770 & & \\
\hline & .628 & & .226 & .798 \\
\hline & .650 & & & \\
\hline \multirow{3}{*}{$\begin{array}{l}\text { Physical/ Structural } \\
6-12 \text { years } \\
13-18 \text { years }\end{array}$} & $\leq 5$ years & .950 & & \\
\hline & .610 & & 2.305 & .107 \\
\hline & .759 & & & \\
\hline \multirow{3}{*}{$\begin{array}{l}\text { Work and School } \\
6-12 \text { years } \\
13-18 \text { years }\end{array}$} & $\leq 5$ years & .146 & & \\
\hline & .959 & & 1.716 & .187 \\
\hline & 1.009 & & & \\
\hline \multirow{3}{*}{$\begin{array}{l}\text { Attitude and Support } \\
6-12 \text { years } \\
13-18 \text { years }\end{array}$} & $\leq 5$ years & 1.576 & & \\
\hline & .556 & & 1.597 & .210 \\
\hline & .417 & & & \\
\hline \multirow{3}{*}{$\begin{array}{l}\text { Policies } \\
6-12 \text { years } \\
13-18 \text { years }\end{array}$} & $\leq 5$ years & 1.115 & & \\
\hline & 1.204 & & .523 & .595 \\
\hline & 1.405 & & & \\
\hline \multicolumn{5}{|l|}{ Magnitude } \\
\hline \multirow{3}{*}{$\begin{array}{l}\text { Service And Assistance } \\
6-12 \text { years } \\
13-18 \text { years }\end{array}$} & $\leq 5$ years & .492 & & \\
\hline & .362 & & .082 & .921 \\
\hline & .339 & & & \\
\hline \multirow{3}{*}{$\begin{array}{l}\text { Physical/ Structural } \\
6-12 \text { years }^{b} \\
13-18 \text { years }\end{array}$} & $\leq 5$ years $^{\mathrm{a}}$ & .714 & & \\
\hline & .214 & & 4.294 & $.018 *$ \\
\hline & .319 & & & \\
\hline \multirow{3}{*}{$\begin{array}{l}\text { Work And School } \\
6-12 \text { years } \\
13-18 \text { years }\end{array}$} & $\leq 5$ years & .568 & & \\
\hline & .613 & & .419 & .659 \\
\hline & .641 & & & \\
\hline \multirow{3}{*}{$\begin{array}{l}\text { titude E Support } \\
6-12 \text { years } \\
13-18 \text { years }\end{array}$} & $\leq 5$ years & .618 & & \\
\hline & .727 & & .920 & .404 \\
\hline & .646 & & & \\
\hline \multirow{3}{*}{$\begin{array}{l}\text { Policies } \\
6-12 \text { years } \\
13-18 \text { years }\end{array}$} & $\leq 5$ years & .821 & & \\
\hline & .652 & & 1.355 & .265 \\
\hline & .546 & & & \\
\hline
\end{tabular}

in the Physical/ Structural domain $(p=0.013)$, where the parents and caregivers of the $\leq 5$ years old group perceived greater barrier magnitude when compared to those aged between 6 and 12 years (Table 4).

\section{DISCUSSION}

This study is the first to explore the prevalence of barriers related to the physical, social and attitudinal environment and their associated factors in a group of children and adolescents with PD from two northeastern states in Brazil. As the ICF proposes, the environment exerts an important influence on different aspects of life, related to functioning and disability ${ }^{15}$.
Indeed, the impact of a child's or adolescent's environment on health and well-being, including participating in daily and leisure activities, has been well documented in people with and without disabilities. However, most studies were conducted in North America, Australia and Europe 24, 43-47.

Our results show that parents or caregivers perceive greater environmental barriers in the Service and Assistance domain, similar to another study carried out in 2013 in Iran, which also used the CHIEF as assessment instrument ${ }^{48}$. This domain includes aspects such as transport, healthcare, adapted personal equipment and social support for disabled individuals and their families. This assistance is usually 
provided by the state, which could explain the similar results in both studies, given that they were conducted in emerging markets with similar economies.

Contrary to our results, a Canadian study, with a sample of children with disabilities and their parents, showed that most barriers perceived by parents were related to the Work and School domain, with Service and Assistance ranked next to last $^{39}$. Such discrepancies reflect two very different contextual realities in terms of policies for children with disabilities. Canada is known for the fight to defend children with disabilities, especially to involve parents and disabled people themselves in decision making and even in the definition of research priorities in the area of disability ${ }^{49}$.

The Physical/Structural domain, which includes aspects related to home and community environments, also obtained high parent perception of barriers. The group of parents with children aged $\leq 5$ years perceived greater barriers than the group of parents of children aged 6 to 12 years, which may be associated with issues such as lack of space at home for children to play safely and public environments suitable to their needs ${ }^{50}$. In the first years of life, parents may be adapting to how to deal with raising a disabled child, in addition to the fact that most children are carried by the parents or caregivers themselves or pushed in strollers, which may increase locomotion difficulties in the physical environment ${ }^{51,52}$.

The lower parent or caregiver perception of barriers was related to the Work and School domain. A multicenter European study of 1174 children with CP showed that the higher the motor impairment, the lower their participation, including in school activities ${ }^{53,54}$. In our study, which included mostly children with CP, the Work and School domain obtained a large number of "never" or "does not apply" answers, since a significant number of children and adolescents with PD did not attend school due to difficulties such as lack of transport or an inclusive school, leading them to drop out at an early age.

Interestingly, parents of children able to walk perceived greater environmental barriers than parents of children who moved about in a wheelchair or baby stroller. Indeed, the literature has reported that children and adolescents with PD who exhibited greater motor impairment took part less in socialization and leisure activities ${ }^{22}$, which may cause parents to have less perception of barriers, given that they are more restricted to the home environment. Children and adolescents with PD in the present study who were able to walk and were thus less disabled, may have faced greater environmental barriers in community environments.

The main guidelines of the National Health Policy implemented in Brazil, which considers the ICF model, are related to promoting quality of life, comprehensive health care, improving information systems and the organization and functioning of services ${ }^{55}$. Despite these efforts, the results of our study showed considerable perception of high-magnitude barriers in the Policies domain, primarily in girls, children and adolescents not diagnosed with $\mathrm{CP}$, who were able to walk and lived in Rio Grande do Norte state. These results seem to indicate that the parents of children and adolescents with disabilities display scant knowledge of these policies or little perception of their effectiveness.As such, in addition to implementing government policies, children and adolescents with disabilities and their families should be empowered to demand and enjoy their rights.

Despite the pioneering nature of this research, it is important to underscore some limitations, such as the use of a convenience sample and non-inclusion of other important variables that could be related to environmental factors. Future studies should include a larger number of participants, especially from other northeastern states in Brazil, a region marked by scarce economic resources, higher disability rates and global health problems.

\section{CONCLUSION}

Environmental barriers referring to Physical/Structural and Service and Assistance domains are perceived more frequently and represent a major problem in both states, however, the frequency and magnitude of barriers referring to the Policies domain, despite being less perceived, are more present in the state of RN. These results lead to a reflection on how each state conducts national public policies aimed at people with disabilities and can be a step toward improving the lives of children with disabilities In Northeast Brazil by turning environmental barriers into environmental facilitators. Recognizing the challenges posed by the environment and society and removing the barriers which prevent child participation may be more effective strategies than trying to modify the body's functioning and structures of children with PD.

\section{AUTHORS' CONTRIBUTIONS:}

LS applied the questionnaires to those responsible for the children and drafted the manuscript. ER conducted training on the instruments to the applicators and critically reviewed the manuscript. IR performed the statistical analysis, assisted in the interpretation of the data, participated in the construction of the results and critically reviewed the manuscript. HN and RS carried out training on the instruments to the applicators and applied the questionnaires with those responsible for children. $\mathrm{CP}, \mathrm{AL}$ and SC coordinated the data collections in the state of Paraíba and critically analyzed the manuscript. EL coordinated the research, assisted the construction of the manuscript and analyzed it critically. All authors read and approved the final manuscript.

\section{CONFLICTS OF INTEREST:}

Nothing to declare.

\section{AUTHORS DETAILS}

${ }^{2}$ Centro Universitário de João Pesoa (UNIPÊ), João Pessoa, PB, Brasil. ${ }_{3}^{3}$ Universidade Federal da Paraíba (UFPB), João Pessoa, PB, Brasil. 


\section{REFERENCES}

1. Organização das Nações Unidas - Brasil: A ONU e as pessoas com deficiência [https://nacoesunidas.org/acao/pessoas-com-deficiencia/] [accessed 2017 Aug 30].

2. Instituto Brasileiro de Geografia e Estatística:Censo Demográfico 2010: Características gerais da população, religião e pessoas com deficiência [http://www.ibge.gov.br/home/estatistica/populacao/censo2010/ caracteristicas_religiao_deficiencia/caracteristicas_religiao_deficiencia_ tab_xls.shtm] [accessed 2017 Aug 29].

3. Instituto Brasileiro de Geografia e Estatística: Pesquisa Nacional de Saúde [https://cidades.ibge.gov.br/] [accessed 2017 Aug 29].

4. Banks LM, Kuper H, Polack S.Poverty and disability in low- and middleincome countries: A systematic review. PLoS One. 2017;12(12):1-19.

5. McConachie H, Colver AF, Forsyth RJ, Jarvis SN, Parkinson KN.Participation of disabled children: how should it be characterized and measured?. DisabiRehabil.2006;28(18):1157-1164

6. Longo $E$, Badia M,Orgaz B, Verdugo MA.Cross-cultural validation of the Children s Assessment of Participation and Enjoyment (CAPE) questionnaire in Spain. Child Care Health Dev. 2014;40(2):231-241.

7. Law M, King G, King S,Kertoy M, Hurley P, Rosenbaum P,et al . Patterns of participation in recreational and leisure activities among children with complex physical disabilities. Dev Med Child Neurol. 2006;48(5):337-342.

8. Beckung E,Hagberg G.Neuroimpairments, activity limitations, and participation restrictions in children with cerebral palsy. Dev Med Child Neurol. 2002;44(5):309-316.

9. Badia M, Longo E, Orgaz MB,Gómez-Vela M. The influence of participation in leisure activities on quality of life in spanish children and adolescents with cerebral palsy. Res DevDisabil. 2013;34(9):2864-2871.

10. Law M,Anaby D, Teplicky R, Khetani MA,Coster W, Bedell G. Participation in the home environment among children and youth with and without disabilities. Br J OccupTher. 2013;76(2):58-66.

11. Ullenhag A,Bult MK, Nyquist A, Ketelaar M, Jahnsen R, KrumlindeSundholm L, et al. An international comparison of patterns of participation in leisure activities for children with and without disabilities in Sweden, Norway, and the Netherlands.DisabilRehabil. 2012;15(5):369-385.

12. Khetani, M, Graham JE, Alvord C. Community participation patterns among preschool-aged children who have received Part $\mathrm{C}$ early intervention services. Child Care Health Dev. 2013;39(4):490-499.

13. Benjamin T, Lucas-Thompson RG, Little LM, Davies P, Khetani M. Participation in Early Childhood Educational Environments for Young Children with and Without Developmental Disabilities and Delays: A Mixed Methods Study. Phys OccupTherPediatr.2017;37(1):87-107.

14. Shikako-Thomas K, Majnemer A, Law M,Lach L.Determinants of participation in leisure activities in children and youth with cerebral palsy: systematic review. PhysOccupTherPediatr.2008;28(2):155-169.

15. Organização Mundial De Saúde - OMS, Organização Panamerica De Saúde - OPAS. CIF - Classificação Internacional De Funcionalidade, Incapacidade E Saúde. São Paulo: Universidade De São Paulo; 2003.

16. Santos PD, Silva FC, Sousa BA, Pires GKW, lop RR, Ferreira EG, et al. Functionality and quality of life of children with disability. J Hum Growth Dev. 2018;28(2):154-164.

17. Organização Mundial De Saúde - OMS. World report on disability. [book online]. 2011. [http://www.who.int/disabilities/world_report/2011/en/] [accessed 2017 Sep 10].

18. Badia M,BegoñaOrgaz M, Gómez-Vela M, Verdugo MA,UllánM, Longo E. Do environmental barriers affect the parent-reported quality of life of children and adolescents with cerebral palsy?. Res DevDisabil.2016;49-50:312-321.

19. Anaby D,Mercerat C, Tremblay S. Enhancing Youth Participation Using the PREP Intervention: Parents' Perspectives. Int J Environ Res Public Health. 2017;14(9):1005.

20. Anaby D, Law M,Teplicky R, Turner L. Focusing on the environment to improve youth participation: experiences and perspectives of occupational therapists. Int J Environ Res Public Health. 2015;12(10):13388-13398.
21. Anaby DR, Law M, Feldman D,Majnemer A, Avery L. The effectiveness of the Pathways and Resources for Engagement and Participation (PREP) intervention: improving participation of adolescents with physical disabilities. Dev Med Child Neurol. 2018;60(5):513-519.

22. Dahan-Oliel N, Shikako-Thomas K, Mazer B,Majnemer A.Adolescents with disabilities participate in the shopping mall: facilitators and barriers framed according to the ICF.DisabilRehabil. 2016;38(21):2102-2113.

23. Seron BB, de Arruda GA, Greguol M. Facilitadores e barreiras percebidas para a prática de atividade física por pessoas com deficiência motora. RevBras Ciênc. Esporte. 2015;37(3):214-221.

24. Alghamdi MS, Chiarello LA, Palisano RJ, McCoy SW. Understanding participation of children with cerebral palsy in family and recreational activities. Res Dev Disabil. 2017;69:96-104.

25. Albrecht EC, Khetani MA. Environmental impact on young children's participation in home-based activities. Dev Med Child Neurol. 2017;59(4):388-394.

26. Palisano RJ, ChiarelloLA, King GA, Novak I, Stoner T, Fiss A. Participationbased therapy for children with physical disabilities. Disabil Rehabil. 2012;34(12)1041-1052.

27. Chiarello LA, Bartlett DJ, Palisano RJ, McCoy SW, Fiss AL, Jeffries L, et al. Determinants of participation in family and recreational activities of young children with cerebral palsy. Disabil Rehabil . 2016;38(25):2455-2468.

28. Khetani M, Little L, Lucas-Thompson R, Davies P, Benjamin T. Participation Disparities Between Children With and Without Disabilities in Early Childhood Educational Environments. Am J Occup Ther. 2015;69.

29. Steinhardt F, Ullenhag A, Jahnsen R, \& Dolva A. Perceived facilitators and barriers for participation in leisure activities in children with disabilities: perspectives of children, parents and professionals. Scand. J. Occup. Ther. 2019: 1-15.

30. Coster W, Bedell G, Law M,KhetaniMA,Teplicky R, Liljenquist K, Gleason $K$, et al. Psychometric evaluation of the Participation and Environment Measure for Children and Youth. Dev Med Child Neurol. 2011;53(11):10301037.

31. Dickinson HO,Colver AF. Measurement of the environment of people with disabilities. Arch Phys Med Rehabil. 2010;91(8):1310-1311.

32. Dickinson HO,Colver A.Sparcle Group. Quantifying the physical, social and attitudinal environment of children with cerebral palsy. DisabilRehabil. 201; 33(1):36-50.

33. Pfeiffer B,Coster W, Tucker C,Piller A. Development and Content Validity of the Participation and Sensory Environment Questionnaire. Occupational Therapy in Mental Health. 2017;13(2):105-121.

34. Harrison-Felix C: Introduction to the Craig Hospital Inventory of Environmental Factors [http://www.tbims.org/combi/chief].

35. Craig Hospital Department Research.Craig Hospital Inventory of Environment Factors [online manual]. 3 ed. Englewood: 2001. [https:// craighospital.org/uploads/CraigHospital.ChiefManual.pdf].

36. Nobakht Z, Rassafiani M, Reza SoltaniP. Validity and Reliability of Persian Version of Craig Hospital Inventory of Environmental Factors (CHIEF) in Children with Cerebral Palsy. IRJ. 2011;9(13):3-10

37. Furtado SRC, Sampaio RF, Vaz DV,Pinho BAS,Nascimento IO, Mancini MC. Brazilian version of the instrument of environmental assessment Craig Hospital Inventory of Environmental Factors (CHIEF): translation, crosscultural adaptation and reliability. Braz J PhysTher. 2014;18(3):259-267.

38. Fleming J, Nalder E, Alves-Stein S, Cornwell P.The Effect of Environmental Barriers on Community Integration for Individuals With Moderate to Severe Traumatic Brain Injury. J Head Trauma Rehabil. 2014;29(2):125135.

39. Law M, Petrenchik T, King G, Hurley P.Perceived Environmental Barriers to Recreational, Community, and School Participation for Children and Youth With Physical Disabilities.Arch. Phys. Med.Rehabi.2007;88(12):1636-1642. 
40. McCauley D,Gorter JW, Russell DJ, Rosenbaum P, Law M, Kertoy M. Assessment of environmental factors in disabled children 2-12 years: development and reliability of the Craig Hospital Inventory of Environmental Factors (CHIEF) for Children-Parent Version. Child Care Health Dev. 2013;39(3):337-344.

41. Vogts N, Mackey, AH,Ameratunga S, Stott NS. Parent-perceived barriers to participation in children and adolescents with cerebral palsy. J Paediatr Child Health. 2010;46(11):680-685.

42. Kertoy MK, Russell DJ, Rosenbaum P, Jaffer S, Law M, McCauley D, et al. Development of an outcome measurement system for service planning for children and youth with special needs. Child Care Health Dev. 2013;39(5):750-759.

43. Imms C, Froude E, Adair B, Shields N. A descriptive study of the participation of children and adolescents in activities outside school. BMC Pediatr. 2016;16:84.

44. Imms C, King G,Majnemer A, Avery L,Chiarello L,Palisano R,et al. Leisure participation-preference congruence of children with cerebral palsy: a Children's Assessment of Participation and Enjoyment International Network descriptive study. Dev Med Child Neurol. 2017;59(4):380-387.

45. Anaby DR, Law MC,Majnemer A, Feldman D. Opening doors to participation of youth with physical disabilities: An intervention study. Can J OccupTher. 2016;83(2):83-90.

46. Imms C, Mathews S, Nicola Richmond K, Law M,Ullenhag A. Optimising leisure participation: a pilot intervention study for adolescents with physical impairments. DisabilRehabil. 2016;38(10):963-971.

47. Anaby D, Law M,Coster W, Bedell G, Khetani M, Avery L. The role of the environment in explaining participation in the home, school and community: Results of a structural equation modelling. Int J Dev Neurosci. 2015;47:53-54.
48. Nobakht Z, Rassafiani M, Rezasoltani P,Sahaf R,Yazdani F. Environmental Barriers to Social Participation of Children with Cerebral Palsy in Tehran. IRJ. 2013;11:40-45.

49. Shikako-Thomas K, Law M. Policies supporting participation in leisure activities for children and youth with disabilities in Canada: from policy to play. Disabil. Soc. 2015: 381-400.

50. Kang LJ, Hsieh MC, Liao HF, Hwang AW. Environmental Barriers to Participation of Preschool Children with and without Physical Disabilities. Int J Environ Res Public Health.2017; 14(5):518.

51. Henderson S, Skelton H, Rosenbaum P. Assistive devices for children with functional impairments: impact on child and caregiver function. Dev Med Child Neurol. 2008;50(2):89-98.

52. Christian HE, Klinker CD, Villanueva K,Knuiman MW, Foster SA, Zubrick SR,et al. The effect of the social and physical environment on children's independent mobility to neighborhood destinations. J Phys Act Health. 2015;12(6): 84-93.

53. Colver A, Thyen U, Arnaud C, Beckung E, Fauconnier J, Marcelli M, et al. Association between participation in life situations of children with cerebral palsy and their physical, social, and attitudinal environment: a cross-sectional multicenter European study. Arch Phys MedRehabil. 2012;93(12):2154-2164.

54. Parkes J, McCullough N, Madden A. To what extent do children with cerebral palsy participate in everyday life situations?.Health Soc Care Community. 2010;18(13):304-315

55. Brasil. Ministério da Saúde. Política Nacional de Saúde da Pessoa com Deficiência [book online]. Brasília: Editora do Ministério da Saúde, 2010. [http://bvsms.saude.gov.br/bvs/publicacoes/politica_nacional_pessoa_ com_deficiencia.pdf] [accessed 2017 Sep 15]. 